\title{
Trực diện 5 nguy cơ
}

\author{
Bùi Tất Thắng \\ Tạp chí Tài chính \\ February 13, 2014
}

http://tapchitaichinh.vn/nghien-cuu--trao-doi/trao-doi-binh-luan/truc-dien-5nguy-co-43033.html 


\title{
Trực diện 5 nguy cơ
}

\author{
PGS., TS. BÙI TẤT THẮNG
}

\author{
09:15 13/02/2014
}

\begin{abstract}
(Tài chính) Phân tích thực trạng kinh tế Việt Nam hiện nay, dựa trên một số chỉ tiêu đánh giá mức độ bền vững của phát triển, so với yêu cầu đặt ra cho thời kỳ tới, một mặt cần ghi nhận những thành tích nhưng mặt khác cần nhận diện thật rõ 5 nguy cơ chủ yếu có thể ảnh hưởng xấu đến tính bền vững của phát triển.
\end{abstract}

Thứ nhất, nhận diện tình hình kinh tế khá khó khăn. Để quản lý, theo dõi, phân tích, đánh giá thực trạng tình hình kinh tế, các số liệu định lượng của các chỉ tiêu kinh tế có vai trò rất quan trọng. Nhưng thực tế, số liệu định lượng các chỉ tiêu cơ bản không dễ tìm, dẫn đến những cách tính toán không giống nhau, cho ra kết quả khác nhau. Các số liệu đánh giá chỉ số ICOR (hiệu quả sử dụng vốn) là một ví dụ. Các báo cáo khác nhau đưa ra những số liệu khác nhau. Nhóm nghiên cứu chính sách của Đại học Harvard trong báo cáo "Sự lựa chọn thành công - Bài học từ Đông Á và Đông Nam Á cho tương lai của Việt Nam", tháng 1/2008, đưa ra số liệu ICOR thời kỳ 2001 - 2006 là 4,4 nhưng TS. Vương Quân Hoàng trong bài viết "Kinh tế Việt Nam 2009 và một vài suy nghĩ về nhận thức luận chuyển đổi", Tạp chí Cộng sản số 3/2010, lại đưa ra số liệu ICOR thời kỳ 2000-2006 là trên 5.

Có thể coi sự khác nhau giữa các ý kiến đánh giá là bình thường nhưng cần hạn chế sự khác nhau về số liệu. Đã đến lúc thống nhất phương pháp xây dựng cơ sở thông tin kinh tế một cách khoa học và hình thành hệ thống thông tin thống kê quốc gia thống nhất, thông suốt và hiệu quả, phù hợp với tiêu chuẩn, thông lệ quốc tế.

Thứ hai, nhập siêu tăng. Trong số những nước nhập siêu ở khu vực, gồm Việt Nam, Campuchia, Lào và Philippines, Việt Nam có mức nhập siêu lớn. Tỷ lệ nhập siêu trên quy mô nền kinh tế của Việt Nam thấp hơn Campuchia và cao hơn hẳn Lào và Philippines, nhưng về số lượng tuyệt đối, Campuchia chỉ nhập siêu 1 tỷ USD.

Có nhiều ý kiến về nhập siêu nhưng tập trung vào các lập luận: Nhập siêu để tiến hành công nghiệp hóa (CNH), nhập siêu do FDI, nhập siêu do tác động của giá cả thế giới. Nhưng thực tế, nhập siêu của Việt Nam không phải được đổi bằng sự thành công mỹ mãn của $\mathrm{CNH}$.

Trong khi xu hướng nhập siêu vẫn gia tăng, những mục tiêu của CNH vẫn còn ở phía trước khá xa. Nhập siêu của Việt Nam cũng không phải chủ yếu do FDI mà chủ yếu do khu vực DN trong nước. Nhập siêu khó có thể kết luận đơn giản chủ yếu do tác động của giá thế giới tăng.

Nếu mô hình phát triển kinh tế và xuất nhập khẩu hiện tại không thay đổi, nhập siêu vẫn tiếp diễn trong dài hạn. Muốn thay đổi cục diện này, cần dứt khoát khẳng định một mô hình CNH mới.

Có thể không gọi là mô hình CNH hướng về xuất khẩu nhưng tinh thần của cạnh tranh, giành thị phần mang tính toàn cầu phải trở thành yêu cầu bắt buộc đối với mọi doanh nghiệp. Thực hiện mô hình này, có thể vẫn phải nhập siêu nhưng được đổi bằng sự hoàn thành quá trình CNH và Việt Nam trở thành nước CNH mới.

Thứ ba, chỉ số giá tiêu dùng, lạm phát và lãi suất cao. Từ năm 2004 đến nay, tốc độ tăng chỉ số giá tiêu dùng (CPI) của Việt Nam thuộc loại cao, trong đó, năm 2008 tăng lên mức 23\%. CPI hàng hóa nói chung năm 2000 là 100 , đến năm 2008 là 179,6\% và năm 2009 là192,0\%, tức là tăng gần gấp đôi trong vòng 10 năm.

Như vậy, chỉ số CPI tính theo sự trượt giá của các giỏ hàng hóa tiêu dùng, tốc độ lạm phát tính theo GDP đo lường mức độ trượt giá của toàn bộ nền kinh tế. Bên cạnh đó, lãi suất huy động và cho vay ở Việt Nam trong những năm qua luôn cao hơn so với nhiều nước khác. Vì thế, khả năng tiếp cận nguồn vốn vay không dễ dàng và việc mở mang kinh doanh để có lãi bị hạn chế.

Thứ tư, nợ công tăng. Việt Nam thuộc nhóm có mức nợ công cao dù số liệu về nợ công chưa thống nhất do cách 
tính toán khác nhau. Tính tới 31/12/2009, nợ công là 52,6\% GDP. Vì vậy, nhiều nhà kinh tế lo ngại tính bền vững của nợ công.

Giai đoạn 2001 - 2009, một xu thế đáng lo ngại đã diễn ra, thâm hụt ngân sách cả trong và ngoài dự toán tăng từ 2,8\% lên mức 9\% GDP. Như vậy, trong khi nợ công tăng liên tục thì ngân sách lại ngày càng trở nên thâm hụt.

Điều này vi phạm một nguyên tắc cơ bản của quản lý nợ công bền vững, đó là nợ công ngày hôm nay phải được tài trợ bằng thặng dư ngân sách ngày mai. Hơn thế, với nhu cầu tiếp tục đầu tư để phát triển, chắc chắn nợ công sẽ còn tăng trong nhiều năm tới.

Cụ thể, với tỷ lệ tiết kiệm nội địa chỉ khoảng 27\% GDP trong khi mức đầu tư toàn xã hội mỗi năm khoảng 42\% GDP, Chính phủ phải tiếp tục đi vay rất nhiều (bên cạnh vốn đầu tư nước ngoài) để bù đắp khoản thiếu hụt. Tuy vẫn trong tầm kiểm soát nhưng nợ công cũng là một yếu tố không được xem nhẹ nếu muốn duy trì sự ổn định nền kinh tế và đảm bảo phát triển bền vững.

Thứ năm, việc làm, thu nhập và tiếp cận cơ hội phát triển đang có xu hướng tích tụ những mâu thuẫn theo thời gian. Liên quan đến điều này là một loạt các vấn đề rộng lớn, bao gồm đất đai, giáo dục và đào tạo, chính sách phân phối, tiền lương... vốn có một số bất hợp lý tồn tại từ trước nhưng chưa được xử lý thấu đáo, triệt để. Cùng với thời gian, vấn đề này ngày càng trở nên bức xúc.

Theo Tạp chí Tài chính doanh nghiệp

In bài viết 


\section{Tài liệu tham khảo:}

[1] FETP. (2008). Sự lựa chọn thành công - Bài học từ Đông Á và Đông Nam Á cho tương lai của Việt Nam. Nhóm nghiên cứu chính sách công, Đại học Harvard.

[2] Vương Quân Hoàng. (2010). Kinh tế Việt Nam 2009 và một vài suy nghĩ về nhận thức luận chuyển đổi. Tạp chí Cộng Sản, 81(1), 49-55.

[3] Phạm Minh Chính \& Vương Quân Hoàng. (2009). Kinh tế Việt Nam: Thăng trầm và đột phá. Nxb Chính trị quốc gia, Hà Nội. 